\title{
Politics should listen to science, not hide behind it
}

\author{
Scientists can provide governments with essential knowledge to take informed decisions, but cannot decide on \\ their behalf, according to Carlo Rovelli.
}

t he governments that have ignored scientific knowledge in the course of the current pandemic have caused damage to their people. A good benchmark can be taken to be Taiwan, which has suffered only a few tens of COVID-19related deaths, compared to the tens or hundreds of thousands of other countries. The Vice President of Taiwan, Chen Chien-jen, is an epidemiologist and Taiwan, an open democratic society, has taken the available scientific knowledge about the virus very seriously, so far with success.

However, this does not mean that the difficult decisions that countries have taken and must still take to face the pandemic must be decided by science. Science is what we know about the virus; it is the ongoing effort to know more and find technical solutions, like vaccines. Science is knowledge, which is the best tool we have. But tools do not decide choices. Our open societies harbour conflicting values and deal with competing interests that tend to clash even more in times of crisis. It is the role of politics, in the most noble sense of this word, to arbitrate and mediate between these competing pulls.

To put it brutally, there have been, and there still are, very hard choices to be made between allowing more lives to be lost versus allowing people to become poorer. Sciences (epidemiology, virology, medicine, economics and other disciplines) can at best offer estimates of the likely relative outcomes of different options. Ignoring these estimates is incompetency or dishonesty, but even in light of our best knowledge, the difficulty of choosing among these options remains. Yet this dilemma is not one that science can solve. There are multiple social values to be considered in this decision: the values of the lives lost because of the lack of measures to contain the contagion, the value of the wealth lost by taking these same measures, the balance between personal freedom and the protection of the health of others, and the value of solidarity in sharing the burden needed to save lives. These aspects are not uniformly weighted in our societies; an open discussion about them must guide and motivate the political decisions taken by governments. We can ask science what possibilities we have, given our current knowledge. We cannot ask science to decide for us.

I write this because I see a danger: that politics hides behind science to justify its choices. I think that this would be wrong, and dangerous both for society and for science. Science should be listened-to, by the governments, but it should not be a screen behind which to hide, to justify hard-to-take decisions. The risk is that a part of society would then blame science, and lose confidence in government, when disagreeing with the choices made. When I hear political leaders saying that they will do what science tells them to do, I worry. This is the wrong message. A more reassuring message from a political leader would be his/her willingness to take the scientific knowledge we have fully into account, and then decide on the basis of a clear value system and a responsible arbitration between interests and values.

History is full of very bad choices made by governments, taken under the cover of science. From the experimentation of psychedelic drugs on unwitting test subjects conducted by US government agencies in the 1950s all the way to the racial policies of the Nazis, examples abound. Even without recurring to these extreme examples, it suffices to remember how often scientific economic theories have been used by governments to justify economic policies that actually favour only one part of the society: an open government should never hide behind science to cover true motives of some choices.

The economic aspects of the decisions to be taken today to face the pandemic are a main reason for which political choices should not be sold as dictated by science. Measures to limit the spread of the virus, from total lockdowns to limitations to travel or to certain economic activities, have a large economic impact. Their costs weigh directly on the shoulders of certain sectors of society. In the course of the pandemic, rich layers of society have become richer, furthering the increase in economic disparity that has characterized the evolution of our social structure in the last decades. Many economic sectors have suffered strongly during the past year, many people have lost their jobs, but the stock market has been thriving, and wealth has further accumulated. In this situation, it is clear that deciding who should pay the economic cost of saving lives is a political question. Is this cost to end up on the shoulders of the majority, or should it be shifted to those sectors of society that have much larger means and have received economic advantages from the current crisis? Is it right that we make a costly collective effort to save lives, but this effort is not shared according to the possibilities of each in contributing to it?

To justify hard requests on the people under the claim of 'following science' is to hide crucial political aspects of the choices involved. I hope that governments pay maximum attention to science, but do not hide behind science to motivate decisions that are complex and dictated by arbitrating between conflicting values, and mediating between conflicting interests - choices that are political, not scientific.

\section{Carlo Rovelli (iD) \\ Aix-Marseille University, Marseille, France.

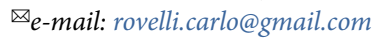

Published online: 4 January 2021 https://doi.org/10.1038/s41563-020-00891-3 